\title{
Legal Ethics in England and Wales
}

\section{Avrom Sherr and Lisa Webley}

\author{
Institute of Advanced Legal Studies
}

\section{The Profession}

The profession in England and Wales is the historical archetype of Common Law Legal Professions. Its distinguishing feature is the division between barristers and solicitors.

Historically, barristers dealt with advocacy or representation of clients before the courts and with high level consultancy on difficult or specialist cases. Solicitors were involved in the office work including all the contact with lay clients directly. Since 1991, it has been possible for solicitors, with an extra qualification, to act as advocates even in the highest courts. Barristers on the other hand, may now deal directly with certain professional clients, without the intervention of a solicitor. Many commentators feel that the two legal professions are in a state of gradual fusion. Solicitors make up the bulk of the legal profession and in 1996 there were 87,081 solicitors on the roll, of which 68,037 held practising certificates. In contrast the barristers' profession has 8,492 members $^{1}$

Most solicitors will need Practising Certificates if they are to be involved in legal work. There are exceptions for those in local government, commerce and industry. In 1996 there were 8,702 firms of solicitors in England and Wales which earned at least $£ 15,000$ per annum, with 4,377 of those firms classified as sole practitioners ${ }^{2}$. There are also some 5,771 legal executives ${ }^{3}$ who qualify separately from both barristers and solicitors, carry out lower level procedural or transactional work and must work under the supervision of solicitors. Since 1986 a further legal profession of Licensed Conveyancers has existed, with the possibility of working separately from firms of solicitors on domestic property transactions. This profession has its own system of qualification and there are some 271 Licensed Conveyancers able to work on a self-employed basis with a further 404 qualified to work as employed within other legal organisations ${ }^{4}$.

This paper examines legal ethics in England and Wales from the standpoint of the solicitor's branch of the legal profession, which is the more numerous being

The Lord Chancellor's Advisory Committee on Legal Education and Conduct First Report on Legal Education and Training, April 1996, p11.

The Solicitors Complaints Bureau Annual Report 1995, Self Regulation in Practice, p4 and trends in Solicitors' Profession. Annual Statistical Report, 1996. The Law Society RPPU. As at 1/2/96 Institute of Legal Executives Report 1966.

As at $6^{\text {th }}$ August 1997 - conversation with Mrs Watson, Deputy Director of the Council for Licensed Conveyancers on that date. 
ten times the number of barristers, and also deals with a wider range of cases, clients and work.

\section{Entry Conditions and Gatekeepers}

There are three main routes to becoming a solicitor, two of which involve attaining an undergraduate degree, the third involving a combination of a more extensive period of vocational training in addition to professional legal education. Most students take one of the two degree routes into the profession ${ }^{5}$. The third route involves qualification as a solicitor through a combination of working as a legal executive in a firm, completing examinations in the core subjects set by the Institute of Legal Executives, and taking the Legal Practice Course (LPC).

\section{The Degree Routes}

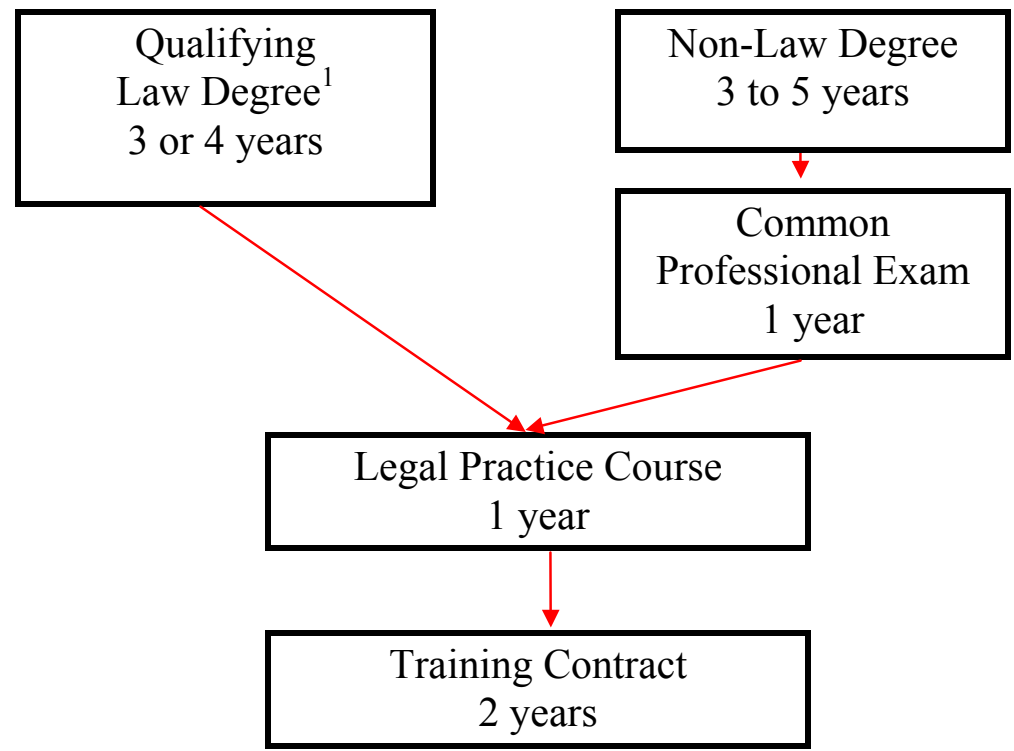

The Common Professional Exam ("CPE") is a one year law conversion course for those who have taken a non-law degree. The ingredients of a "Qualifying Law Degree" and of the CPE have long been a subject of contention between the universities and the legal professional bodies, the Law Society and the Bar. Until recently there was a fair degree of prescription for the content and assessment methods of approximately half of the subjects taken in a Qualifying Law Degree. In this way the professional bodies held considerable control over both content and approach. Now that grip has loosened ${ }^{6}$, undergraduate degree programmes may be searching out their own "core" of subjects. It may take some time for legal educators to understand what the new freedom will allow. The right to exercise any control derives from the profession's desire for graduate entry, coupled with the desire of undergraduate students to qualify as practitioners. There are no statutory regulations (compare the position in Germany) which specify what might be contained within a

5 Richard de Friend, International Journal of the Legal Profession Vol. 2 No 11995 pp.119-146

6 See below and Saunders, N 30 Law Teacher 2 pp.168-186 
law degree. The profession has been able to dictate half the contents of the law degree since they can decide what sort of degree will enable people to qualify as lawyers. Now that less than half of the students graduating from universities with law degrees will end up in the legal profession, the basis for this control has inevitably become less strong. But it is not known at the beginning of a degree programme, either by the students or by the universities, which students are likely to go on to practice. Indeed, it is fairly clear that some $80 \%$ still seek legal practice as a likely option $^{7}$.

There has been some controversy over aspects of the CPE. Both the Bar and the Law Society have been interested in attracting students who have not necessarily taken law as a first degree but still wish to practice as lawyers. These can include students from a range of disciplines. Non-law students have been most attractive during periods of growth in the profession. They may qualify as lawyers if they take the CPE. The battle between academics and the profession has been fought over how long the CPE should take, what subjects should be taught, and whether students from other disciplines can be assumed to have some of the "training of the mind" which is said by the protagonists to be at the root of legal education?

The battle has largely been fought by academic lawyers who have seen these nonlawyers as being able to come into legal practice "through the back door". Often their school leaving (A-Level) scores will not have been anywhere near as good as those of the law students, since the discipline of law is most difficult to get into. In an almost punitive fashion these academics have demanded more than a one year conversion course ${ }^{8}$. This is an argument which seems destined to continue, but it shows an interesting set of tensions ${ }^{9}$. Within the undergraduate degree the fight between law faculties and the legal profession has, in the past, seen the legal profession demanding more subjects and particular approaches than the law faculties would wish. With regard to the CPE the position is reversed. If students can enter law more easily through other disciplines this would, in the long term, undermine the numbers going into law degrees and therefore the status of the law degree. A competition of interests is therefore at play in which the legal profession is not the only party trying to safeguard its future.

\section{$\underline{\text { Undergraduate Legal Education }}$}

In $1995,8,576$ students graduated with law degrees from universities ${ }^{10}$. Candidates for places on a law degree programme will usually be required to meet a specified educational standard (often a score of $\mathrm{ABB}$ at ' $\mathrm{A}$ ' level or higher). They may also be interviewed by the university in order to decide whether they are suitable for the programme of studies. At this point the main hurdle to obtaining a place is academic, although financial considerations increasingly play a role. With the growth in the number and range of institutions now offering law degrees, the number of available places almost doubled between $\underline{1985}$ and $\underline{1995}$, allowing a more socially representative group of students to read law. The growth in the number of law students included a

\footnotetext{
$7 \quad$ PSI Cohort Study Year 31996.

8 See E.G. Birks, P. 1995, Webb Jo.of Current Legal Issues.

9 See ACLEC First Report on Legal Education, 1996.

$10 \quad$ The Law Society Annual Statistics Report 1996 p. 68.
} 
considerable growth in the proportion of female students entering law (now at around $52 \%$ ). Females entering law came from a very similar social background to the males who had been there before them ${ }^{11}$.

\section{The Vocational Stage Of Training}

Following one cohort through the system, the class of 1995, in the following academic year, 1995-1996, saw 9,849 applications to study the Legal Practice Course full-time, resulting in an enrolment of 6,921 full-time students and 954 part-time. With a total of 8,576 law graduates (see above), the remainder of these applicants are likely to be non-law graduates who have completed the CPE (or law graduates from previous years).

In 1993, the vocational stage of training had undergone major changes. The number of places on the LPC were increased from approximately 5,500 in 1991-2 and now stand at $6,800^{12}$, a (24\% increase). Anecdotal evidence suggests that the major factor which now determines whether a student will take up a place is not as previously whether there are places on the LPC available for students, but whether they have funding for the course fees of around $£ 5,000^{13}$. If the student has a training contract arranged with a large commercial firm before commencing the vocational stage of training then in many cases the fees and a living allowance will be met by the firm. Otherwise the student will have to be self-financing either through their parents, their own resources, or a bank loan. This therefore places a restriction on the range of people who will continue on to the vocational training stage.

An analysis of the ethnic origin of applicants is also undertaken for students who apply for a place on the LPC in order to monitor access to the profession at this stage of training ${ }^{14}$. For example the number of first choice applications for 1994-5 was 9,844, the number of ethnic origin response forms returned is 9,123. (A response rate of $92.7 \%)$.

Table I- Comparison of Applications, Offers from First Choice Institution, and Acceptances by White and Ethnic Minority Candidates

\footnotetext{
11 Sherr, A 1994 International Journal of the Legal Profession p.1-12

12 The Law Society Annual Stastistics Report 1996 p.72

13 PSI Cohort Study Year 3, 1996.

14 The figures are supplied by the Central Applications Board, Ethnic Monitoring Analysis.
} 


\begin{tabular}{|l|c|c|c|c|c|c|}
\hline 1994-5 $^{\mathbf{1 5}}$ & \multicolumn{2}{|c|}{ Applied } & \multicolumn{2}{c|}{$\begin{array}{c}\text { Offers from 1 } \\
\text { Choice }\end{array}$} & \multicolumn{2}{c|}{ Acceptances } \\
\hline & LPC & CPE & LPC & CPE & LPC & CPE \\
\hline White & $80 \%$ & $(83 \%)$ & $84 \%$ & $(86 \%)$ & $72 \%$ & $(86 \%)$ \\
\hline $\begin{array}{l}\text { Ethnic } \\
\text { Minorities }\end{array}$ & $20 \%$ & $(17 \%)$ & $60 \%$ & $64 \%$ & $68 \%$ & $(54 \%)$ \\
\hline
\end{tabular}

Ethnic minority applicants seem to receive a lower proportion of $1^{\text {st }}$ choice offers than their white counterparts and their acceptance rate of others is also lower ${ }^{16}$.

\section{Training Contracts And The Profession}

It is noticeable that although about 7,800 students studied the LPC, during 1995-96 (full and part-time) only 4,063 training contracts were registered with the Law Society that year. This is not a direct comparison between the number of students who took the LPC and their success in attaining a contract to train as a solicitor. Of those 4,063 training contracts, some may have gone to students who completed their vocational stage of training in a previous year, and those who completed the LPC in 1995 may not have started their training contract until the following year. It does however show that there is a deficit in the number of training contracts offered each year, thus allowing firms to select trainees from a large pool of candidates as opposed to trainees choosing the firm in which they wish to work. In the last year numbers of people taking the LPC appears to be dropping and the gap between these and the numbers of training contracts may be narrowing.

This is where the bottleneck in entry is to be found and therefore it is the solicitors' firms who act as the gatekeepers of the profession. The largest $5 \%$ of firms in England and Wales employ around $40 \%$ of the total solicitors in private practice, offer the majority of training contracts and funding, and therefore control this selection process. According to the Law Society Cohort Study, it appears that the marks attained in the second year of law exams, or the first degree classification in the case of non-law students, are a determining factor in attaining a training contract. In addition attendance at Oxbridge was considered to be an advantage, followed by an old university over a new one. Having relatives in the profession, or attending an independent school were also favoured, although age and gender did not appear to make a significant difference to a candidate's chances (although women said they found it harder to obtain contracts, this was not shown up by the figures of articles obtained). Ethnicity however was shown to play a major role in success or failure in securing a training contract. The most recent report on the cohort study ${ }^{17}$ suggests that class may be as much, or more of a problem in obtaining a training place (see later) than race. 
Graph 1- Success In Getting A Training Contract, White And Ethnic Minority Students $^{18}$

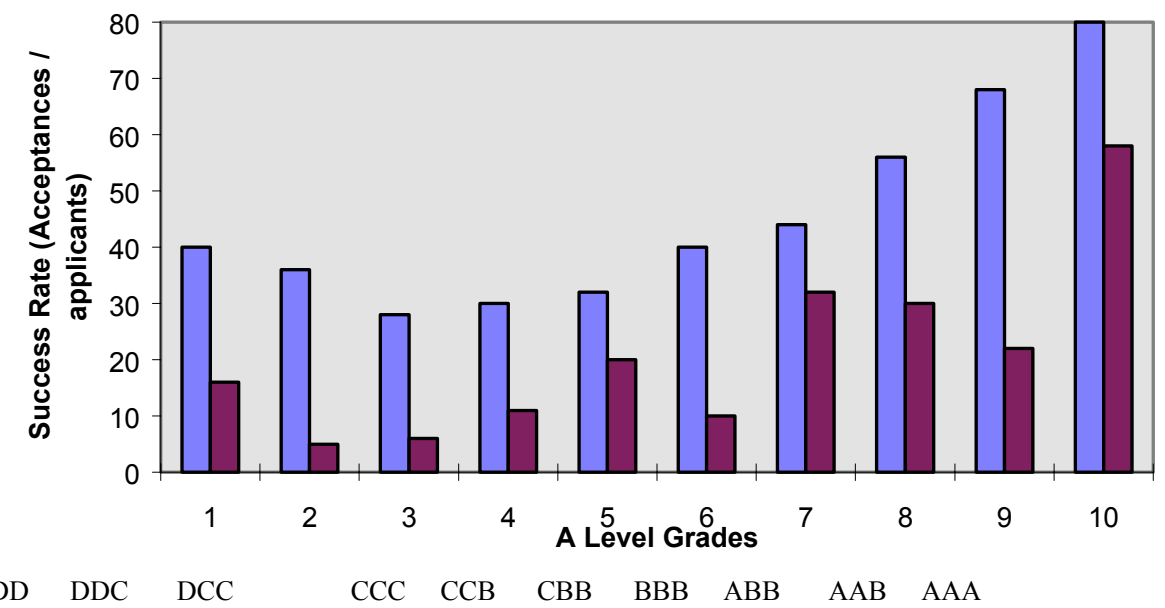

This Bar Chart looks at the 'A' level scores of those applying for articles and compares the success of ethnic minority and other applicants in obtaining a training contract against these grades. 'A' Levels are used because they are likely to be more standardised than degree classifications across different universities. Whether an applicant has obtained three A's at 'A' Level (10 in the bar chart) or three D's at 'A' Level ( 1 in the bar chart) there will be less likelihood for ethnic minority applicants to obtain training contracts. Ethnicity is therefore an important barrier to becoming a solicitor, since the training contract controls entry into the legal profession.

Separate, recent research by the Trainee Solicitors Group on recruitment managers in larger firms suggests that academic intelligence is the key selection criteria. 22/23 year old law graduates are generally preferred, provided they are talented all rounders who fit in well with the firm. "Non-traditional" applicants are probably disadvantaged $^{19}$. This would probably affect mature students, or people from a different race or class origin of those carrying out the hiring.

\section{Self Governance, Self Administration And Self Judging In Relation To Setting Rules And Assessing The Breach.}

In the past the Law Society has regulated its own affairs through the Solicitors' Code of Practice, its Guide to the Professional Conduct of Solicitors and through its

$18 \quad$ Ibid p. 80.

19 Trainee Solicitors Group - Survey of Recruitment Managers of LETG, 1996 
complaints handling system under the Solicitors Complaints Bureau, now the Office for the Supervision of Solicitors. Until relatively recently the larger part of the Code has regulated the relationships of lawyers amongst themselves and paid less attention to the needs of the client or society as a whole. The current edition, the $7^{\text {th }}$ (1996), stands at 698 pages (it was previously 845 pages and there are suspicions that the font size has now been reduced!) also goes some way to establishing rules which require solicitors to act in a competent manner on behalf of their clients - a minimum requirement of competence.

This change in focus of the Code did not however occur sufficiently quickly to offset the perceived concern by the public about the way the legal profession handled complaints or dealt with the question of high solicitors' costs. The Courts and Legal Services Act was introduced in 1990, in a period of deregulation of British institutions and services. It allowed more open competition between the profession and other service providers such as the financial services sector. In that sector a plethora of new regulations appeared to regulate new service providers and the detail of these provisions began to affect solicitors as well. These include guidance on how solicitors should conduct themselves with non-solicitors who are acting for another party in a case $\mathrm{e}^{20}$.

Section 19 of the Courts and Legal Services Act 1990 set up the Lord Chancellor's Advisory Committee on Legal Education and Conduct (hereafter ACLEC) to oversee proposals for changes to the rules of conduct. The committee is made up of a chairperson who is a High Court or Appeal Court Judge and 16 other members. These are appointed by the Lord Chancellor after consultation, and are made up of one circuit judge 2 practising barristers, 2 practising solicitors, 2 law teachers, and 9 others who are from none of the above categories. The members of the committee serve for a maximum term of 5 years.

Schedule 4 of the Act sets out the procedure by which the Law Society and the Bar must seek approval from ACLEC for any changes it wishes to make to its conduct rules or qualification regulations. It is uncertain whether ACLEC must see every change to the rules of conduct specified by the Law Society and the Bar under the Schedule for procedure ${ }^{21}$. It is clear that they must see all changes to the rules which relate to the authorisation or conduct of advocacy and litigation. But, it is not clear which other rules need go to the committee for the application procedure which Schedule 4 sets out. Section 6 states that the Advisory Committee is required to look at and advise on draft amendments to the rules in order to ensure that they:

(a) further the statutory objectives as set out in the Act:-

S17 (1) States that the general objective of this Part of the Act "is the development of legal services in England and Wales (and in particular the development of advocacy, litigation, conveyancing and probate services) by making provision for new and better ways of providing

\footnotetext{
20 A Guide To The Professional Conduct Of Solicitors 1996, p. 409 Annex 25A- Dealing With Unqualified Conveyancers.

$21 \quad$ See ACLEC Annual Report, 1996.
} 
such services and a wider choice of persons providing them, while maintaining the proper and efficient administration of justice".

and

(b) comply with the general principles of the Act:-

S17 (3) States, as a general principle that "the question whether a person should be granted a right of audience, or be granted a right to conduct litigation in general to any court or proceedings, should be determined only by reference to:-

(a) whether he is qualified in accordance with the education and training requirements appropriate to the court or proceedings;

(b) whether he is a member of a professional or other body which-

(i) has rules of conduct (however described) governing the conduct of its members;

(ii) has an effective mechanism for enforcing the rules of conduct; and

(iii) is likely to enforce them;

(c) whether in the case of a body whose members are or will be providing advocacy services, the rules of conduct make satisfactory provision in relation to court proceedings in question requiring any such member not to withhold those services:-

(i) on the ground that the nature of the case is objectionable to him or to any section of society;

(ii) on the ground that conduct, opinions or beliefs of the prospective client are unacceptable to him or any section of the public;

(iii) on any ground relating to the source of financial support which may properly be given to the prospective client for the proceedings in question (for example, on the ground that such support will be available under the Legal Aid Act 1988); and

(d) whether the rules of conduct are, in relation to the court or proceedings, appropriate in the interests of the proper and efficient administration of justice.

S17(5) States that rules of conduct which allow a member of the body in question to withhold his services if there are reasonable grounds for him to consider that, having regard to:-

(a) the circumstances of the case

(b) the nature of his practice; or

(c) this experience and standing, 
he is not being offered a proper fee, are not on that account to be taken as being incompatible with the general principle".

In order for the Law Society to gain approval for its changes, the draft proposals plus supporting documentation are referred to the Committee by the Lord Chancellor. The Committee may then make recommendations. In addition, under Schedule 4 senior designated judges also consider the proposals and may make recommendations. In order for the Law Society to have the approval of the Advisory Committee it must demonstrate that it has complied with the advice of both the Committee and the judges.

\section{$\underline{\text { Legal Education and Ethics }}$}

The second function which ACLEC has been given is in relation to legal education. Schedule 2 paragraph 1 (1) of the Act states that the Committee has a duty to :

(a) keep under review the education and training of those who offer to provide legal services;

(b) consider the need for continuing education and training for such persons and the form it should take; and

(c) consider the steps which professional and other bodies should take to ensure that their members benefit from such continuing education and training.

Schedule 2 paragraph 1 (2) further establishes that the Committee must "give such advice as it thinks appropriate with a view to ensuring that the education and training of those who offer to provide legal services is relevant to the needs of legal practice and to the efficient delivery of legal services to the public."

The Committee therefore has within its remit to review the form and content of the academic and vocational stage of training, but in addition continuing education for those solicitors who are already in practice. In its First Report on Legal Education, the Committee voiced a concern that as the legal profession becomes larger, and instability in the market increases, professional standards will slip and that ethical behaviour will become the first casualty unless steps are taken to ensure that this is not the end result.

The Committee has seen its power increase in the field of professional conduct. The Committee does however point out that along with external regulation, it is important to maintain and improve ethical standards within the profession, and that teaching codes of practice in themselves will not automatically produce ethical lawyers. There is a commitment to continuing to teach ethics in the legal context, but not necessarily in a pervasive manner within existing subject courses. Ethics are defined in the ACLEC First Report not only in terms of the lawyer's relationship with their client, but also the duty which they owe to the wider population. Such duties also extend to legal educators to ensure that the legal education system does not favour the privileged at the expense of minorities, thus enforcing inequalities in the legal profession. $^{22}$

22 The Lord Chancellor's Advisory Committee on Legal Education and Conduct. First Report On Legal Education And Training, April 1996 pp. 17-18. 
ACLEC then has a wide role in advising on any changes in the conduct rules, keeping an overview on legal services generally and handling any applications for the creation of new rights to carry out elements of legal services. This role goes hand in hand with the advisory overview which it provides for legal education.

In relation to changes in conduct rules its most important function in its first five years has been to consider the solicitors' application for Higher Court Rights of Advocacy, and the training regulations associated with these. In relation to such issues, the committee appears to hold something of a balance between the needs of rival elements of the legal profession (such as solicitors and the Bar) and the needs of society at large and clients.

\section{The Complaints and Discipline Systems}

In this section the complaints systems of both the legal and medical professions are considered. By looking at how legal and medical professions undertake complaints handling in each country under study, it is hoped that cultural differences which relate to both professions in each country will become more obvious. This will allow a better understanding of issues which are specific to the legal professions across all jurisdictions $^{23}$.

\section{The Legal Profession}

The solicitors branch of the legal profession now carries out its complaints regulation system through the Office for the Supervision of Solicitors (OSS). Previously until September 1996 this was called the Solicitors Complaints Bureau, whose mission statement was "To strengthen and maintain the confidence of the public and the profession in the conduct and service of solicitors." The profession has the ability to handle its own complaints and its system of professional discipline. Consequently, it has to bear the cost of meeting this requirement. There is also the possibility of an appeal by the complainant to an independent body, the Legal Services Ombudsman (LSO), if the complaint is not handled effectively. The effectiveness of the solicitor complaints handling procedure in England and Wales was the subject of an important National Consumer Council's report into the Solicitors Complaints Bureau in $1994^{24}$. On a postal survey of a sample of complainants who had taken their case to the SCB, two thirds of the 2,246 stated that they were very dissatisfied about the service they received. The Legal Services Ombudsman's reports also demonstrate considerable criticism of the S.C.B ${ }^{25}$

The Law Society as a result have begun to implement some reforms of the SCB which has been renamed the Office For The Supervision Of Solicitors. This is said to include a majority of lay members and a lay-chair person and an emphasis on the need

\footnotetext{
23 It also corresponds with Dietrich Rueschesmeyer's approach to the two classical professions. "Doctors and Lawyers: A Comment On The Theory Of The Professions" 19642 Canadian Rev of Sociology and Anthropology 17

24 The Solicitors Complaints Bureau A Consumer View. National Consumer Council, December 1994

25 Reports of the Legal Services Ombudsman 1993 - 6
} 
for solicitors to operate an effective in-house complaints handling procedure, which is already mandatory under rule 15 of the Solicitors' Code. The aim is to solve as many disputes without the need to involve the OSS, which will therefore become involved only with the more serious cases when a solution cannot be found between the parties themselves ${ }^{26}$.

The previous complaints system was in operation since 1991 when the complaints handling procedure of the Law Society, until then carried out within the confines of the Law Society itself, was delegated to the Solicitors Complaints Bureau. As the SCB became the OSS in 1996, it is not yet clear whether there are major substantive differences in the renamed organisation. As the OSS has not yet produced its first report, this account is taken from the most recent report of its predecessor, the SCB. The SCB/OSS exercises its function by virtue of powers delegated by the Council of the Law Society as provided by s79 of the Solicitors Act 1974. It in turn delegated some of its functions to the Adjudication And Appeals Committee (now the "Compliance and Supervision Committee") which likewise delegated some power to sub-committees. The SCB/OSS therefore works under a Law Society committee although it has separate offices and staff.

The SCB/OSS can investigate complaints relating to professional misconduct and inadequate professional services. It may refer the complaint back to the firm in order for the firm to invoke its internal complaints procedure. If this does not lead to a resolution of the conflict, or if the case is unsuitable for referral then it may handle the matter itself by attempting to facilitate conciliation between the parties, or take further action against the firm or solicitor. In turn the solicitor is required to promptly and efficiently deal with all enquiries and correspondence from the OSS, and provide a satisfactory explanation of his or her conduct- ss12-13A Solicitors Act 1974. In addition the OSS can require the solicitor to hand over the case file.

The OSS, has the power to:

- rebuke the solicitor for professional misconduct

- where it is found that the professional services offered by the solicitor were inadequate under s37A and Schedule 1A of the Solicitors Act 1974, the $\mathrm{SCB} / \mathrm{OSS}$ has the power to:-

disallow all or part of the solicitor's costs, direct the solicitor to rectify the error direct the solicitor to pay compensation to the client up to a limit of $£ 1,000$ direct the solicitor to take at his or her own expense such other action in the interests of the client as the OSS may specify.

- to require a solicitor to pay interest under rule 25 of the Solicitors' Accounts Rules 1991.

- to refuse a practising certificate or to issue one subject to a condition, s12 Solicitors Act 1974, or to impose conditions on a current certificate under 
s13A of the SA1974.

- to suspend, withdraw or impose conditions on an investment business certificate require a solicitor to pay interest under rule 25 of the Solicitors Accounts Rules 1991

- in the case of undue delay, to appoint an agent to recover money and or papers for a client for a new solicitor.

- order an inspection of the solicitor's accounts under rule 27.

- intervene in a solicitors practice under Schedule 1 of the SA 1974.

- institute disciplinary proceedings before the Solicitors' Disciplinary Tribunal.

The Structure Of The Solicitor Complaints Bureau_ and the Office for the Supervision of Solicitors

The SCB had two functions, consumer complaints handling to which $20 \%$ of its staff are dedicated, and professional complaints and regulation of the profession dealt with by the other $80 \%{ }^{27}$. It is thought that initially at least, the OSS will operate in a similar fashion. All cases go to the Primary Investigation Unit in the first instance. It attempts to resolve the complaint either by referring it back to the solicitor who should invoke their in-house complaints procedure (Practice Rule 15) or through mediation or conciliation. If this is not possible, the complaint is then passed on to a specialist unit within the Office which will investigate the matter further. Where a case has received much publicity, or where it is against a member of the Council of the Law Society, an independent solicitor rather than a member of the Office's own Conduct Unit investigates the complaint.

If the matter is not within the ambit of the OSS, it will write back to the complainant explaining which body would be able to take the matter further e.g. in negligence cases the complainant will be advised to instruct a specialist solicitor and contact the Solicitors' Indemnity Fund.

The two specialist units to which cases are usually referred by the Primary Investigation Unit are the Professional Services Unit (PSU) which deals with cases primarily involving complaints of bad service from the public and the Conduct Unit which deals primarily with cases involving alleged breaches of the conduct rules from solicitors. They investigate matters in more detail if there appears to be a case to answer and if the matter is not resolved. In 1995, out of the 18,966 complaints made about solicitors to the SCB, 4,388 cases were referred to the PSU, and 2,028 were referred to the Conduct Unit. In addition the Primary Investigation Unit can also refer cases directly to the Adjudication and Appeals Committee, although more usually

27 ibid p. 8. No Annual Report has been published since the OSS took over from the SCB in 1996. A Background Information Sheet suggests new terms for the work carried out but these may not connote any material differences. A new Annual Report is currently expected at time of publication. 
appeals are mounted in the Adjudication and Appeals Committee. The Complaints procedure can be summarised as shown in the diagram below.

In 1995 the Adjudication and Appeals Committee was made up of a Chair who was a member of the Council of the Law Society, a secretary and 14 members who served for the full year- 3 were Council members, 3 were solicitors who were non-council members, and 9 were lay members. The members who did not serve for the full year in 1995 were, for the first part of the year: 4 Council members, 2 lay members, and for the latter end of the year 5 Council members and 1 solicitor who was a nonCouncil member. Consequently the power balance within the Adjudication and Appeals Committee shifted in favour of the solicitor faction from 11 solicitors and 11 lay members to 13 solicitors and 9 lay members.

The circumstances of complaints against solicitors can be summarised thus ${ }^{28}$ :

No. of practising solicitors

66,123

No of practitioners per 10,000 inhabitants

No. of complaints made to SCB against 18,017

solicitors in 1995.

No. of complaints per 100 practitioners

No. of complaints heard by the Solicitors'

Disciplinary Tribunal in 1995

Percentage of filed complaints heard by

the Solicitors' Disciplinary Tribunal

No. per 100 practitioners

No. of serious sanctions $\quad 92$

$\begin{array}{ll}\text { No. per } 100 \text { practitioners } & 0.14\end{array}$

Of the18,966 complaints which were made to the SCB in $1995^{29}$, around $95 \%$ were against solicitors. This is $3.5 \%$ less than the previous year. Of those complaints less than half came from lay- complainants, and $22 \%$ came from other solicitors. Although no further information is given in the SCB report, it is thought that other complaints could come from (say) barristers, the courts, the Legal Aid Board and others.

With serious breaches of professional conduct rules and principles, the OSS can initiate proceedings through the Solicitors Disciplinary Tribunal.

28 Solicitors Complaints Bureau Annual Report, supra, p. 4

29 Solicitors Complaints Bureau Annual Report 1995, supra, p. 4 
In 1995:

268 solicitors and clerks appeared before the Solicitors Disciplinary Tribunal.

95 solicitors were struck off the roll or indefinitely suspended.

62 firms were subject to intervention by the Law Society ${ }^{30}$.

975 cases were reported on by the LSO, 715 required no further action.

Reprimands include rebukes and fines.

Serious sanctions include suspension or being struck off the roll.

The cost of the SCB to the profession in 1995 was $£ 13.2$ million. $54 \%$ of this involved expenditure on default, some of it preventative in nature. Complaints handling amounted to $40.5 \%$.

\section{The Solicitors' Disciplinary Tribunal}

The Solicitors' Disciplinary Tribunal (SDT) was established by s46 of the Solicitors Act 1974. It is made up of solicitors who have at least 10 years qualification, and lay members who are appointed by the Master of the Rolls.

The Tribunal hears complaints relating to unbefitting conduct and breaches of the professional conduct rules (ss43-44, 46-48 and 54-55 of the SA 1974). The Tribunal also has jurisdiction to hear applications for restoration to the Roll by former solicitors. This is not an appeal jurisdiction. Instead the SDT has to decide whether the applicant can demonstrate that they are a fit and proper person to have their name restored to the Roll.

The Tribunal has the power to impose fines up to a maximum of $£ 5,000$ and to either suspend or strike-off a solicitor. If the offence is a minor one then the sanctions are of a very low level. These can be categorised in four ways - the solicitor's behaviour can be "deprecated", the solicitor can receive a rebuke, a severe rebuke or a Chairman's rebuke. This amounts to a public rebuke of the solicitor in the Law Society's Gazette.

In cases of professional misconduct, the standard of proof which is required is beyond reasonable doubt, the criminal law standard of proof. This is much higher than the standard which is required in a case of Inadequate Professional Service, in which the civil standard of proof has to be met, namely on the balance of probabilities. Although the Legal Services Ombudsman (LSOs) believes that the higher standard of proof is necessary in cases where the solicitor may be struck off or suspended, it feels that at present the procedure is unfairly weighted in favour of the solicitor in

30 This could arise from the accounts audit and monitoring system, complaints or internal requests within a firm. 
instances where a fine may be imposed and where a practice rule or principle is vague $^{31}$.

The applicant may appeal from the Tribunal to the High Court or the Master of the Rolls under s49 of the SA 1974.

$\underline{\text { Legal Services Ombudsman }^{32}}$

If a complainant is unhappy about the way in which their case has been handled by either the Law Society or the Bar Council an appeal may be made to the Legal Services Ombudsman. The LSO is funded by the tax-payer.

New complaints referred to the Legal Services Ombudsman in 1995 totalled 2,092. This was an increase of $31 \%$ on the previous year's complaints. The total complaints considered by the Ombudsman in 1995 was 2,910, with 818 of those being outstanding from 1994. 271 cases failed to meet the criteria for further investigation, 26 cases were discontinued, and 556 are pending as a result of lack of information to allow the case to be pursued at present. Consequently 1,041 cases were investigated and a report was prepared. Of these reports 4 related to Licensed Conveyancers, 65 related to barristers, and the remaining 972 to solicitors. 1,789 formal investigations were undertaken. The balance of the claims are either pending or awaiting final report.

The action recommended as a result of investigations of solicitors was as follows:

The solicitor should compensate the complainant- 68

The Solicitors Complaints Bureau should compensate- 55

The Solicitors Complaints Bureau should reconsider its decision-69

A formal criticism was made of the Solicitors Complaints Bureau- 68

No recommendation or criticism made- 721

The 972 reports which were made in respect of solicitors related to firms with numbers of partners as follows: ${ }^{33}$

Number Of Partners

Sole practitioner

2-4

5-10

$11+$

Not recorded

Total
LSO Reports

$133(14 \%)$

$314(32 \%)$

$194(20 \%)$

$114(12 \%)$

$217(23 \%)$

$972(100 \%)$
Number Of Such Firms

In England And Wales

$3,435(40 \%)$

$3,617(43 \%)$

$1,052(12 \%)$

$420 \quad(5 \%)$

$8,524(100 \%)$

$31 \quad$ ibid, p. 10

Fifth Annual Report of the Legal Services Ombudsman 1995, London HMSO, 1996

Fifth Annual Report of the Legal Services Ombudsman 1995, supra, p.33, Table 7 
$\underline{\text { Solicitors Complaints Procedure } 1995^{34}}$

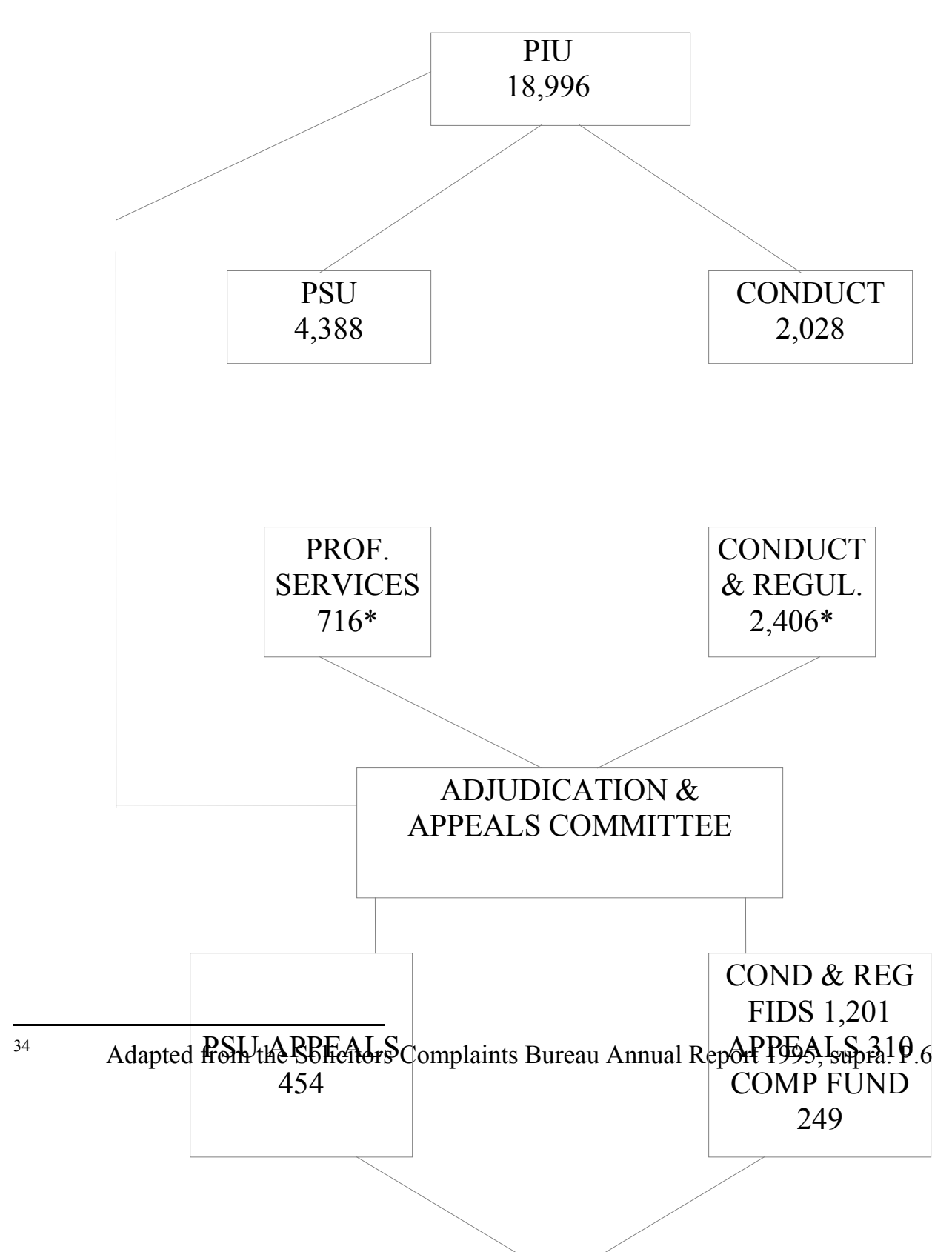




\section{The Medical Profession}

Regulation of the Legal Profession can be contrasted with that of the medical profession in England and Wales. A complaint about professional conduct of a doctor may be made to the General Medical Council where serious professional misconduct is alleged. The GMC is a Council made up of both doctors and lay members, whose functions are outlined in the Medical Act of 1983. The Council's duty is first and foremost to safeguard the medical interests of patients, which entails keeping a register of qualified doctors and considering whether doctors who are subject to a complaint of serious professional misconduct, or who have been convicted of a criminal offence, should be removed or suspended from the register. Complaints can be made by anyone and there is no time limit in which a complaint must be brought, although there may be legal and practical difficulties if complaints are not brought within a reasonable period of time. The GMC does not usually review complaints made about the doctor's clinical judgement, about the level of fees charged by a doctor, nor about a doctor's personal circumstances or behaviour. The GMC is also not able to award compensation to a complainant, this must be sought through a civil or criminal action in the courts.

When the complaint is received at the GMC it is normally referred to a doctor who is a member of the Council. This preliminary screener reviews the complaint to see whether it falls within the remit of the GMC and whether there appears to be a complaint which can be proved on the basis of the evidence provided. The complaint could then be rejected on one of those two grounds, or the preliminary screener will ask the complainant to make a sworn statement of the complaint, and may also ask the same of any witnesses mentioned in the complaint. These statements will then normally be sent to the doctor, who is the subject of the complaint to allow for comments to the GMC. The complaint and the doctor's comments may then be forwarded to the GMC's Preliminary Proceedings Committee for consideration.

The Preliminary Proceedings Committee is made up of a Chairman, eight other doctors and two lay members, a total of 11 members, plus a senior barrister who is available to advise on points of law. The Preliminary Proceedings Committee will consider the sworn statement and the doctor's comments and decide whether the case is suitable to be referred to the GMC's Professional Conduct Committee for a public hearing. The Professional Proceedings Committee can either refer the case to the Professional Conduct Committee, send a letter of warning to the doctor or advise the doctor, or take no further action. The complainant and the doctor will both be informed of any action or decision taken by the Professional Proceedings Committee. Meetings of the Professional Proceedings Committee are held in private three times a year and are confidential.

If the case is referred on to a Panel of the Professional Conduct Committee, a public hearing will take place in London, usually in March, July or November/December of that year. These cases may be reported by the media and the doctor and the complainant may attend. This committee is made up of a chairman, eight other doctors, two lay members and once again a senior barrister to advise on points of law. The proceedings are organised in a quasi court setting and are conducted along the lines of a criminal trial. If the complainant so wishes, the Council will provide a 
solicitor at the Council's expense to represent the complainant, or alternatively the complainant can instruct their own solicitor, although Legal Aid is not available for this. The GMC may on request, contribute towards the reasonable legal expenses of the complainant. The Professional Conduct Committee is required to consider whether the facts of the charge/complaint are proved beyond reasonable doubt. If they are it must consider whether the doctor's behaviour amounted to serious professional misconduct, and if so, whether any action be taken to either remove the doctor from the register, or to restrict his practice in any way. If the Professional Conduct Committee decides that the doctor is guilty of serious professional misconduct, it can:-

"Admonish the doctor" whilst not affecting the doctor's status on the register.

Impose conditions on the doctor's registration, for example require some form of retraining or restrict the doctor's licence to prescribe certain drugs.

Suspend the doctor from the register for a specified period, or

Remove the doctor from the Register.

The Professional Conduct Committee is not able to award compensation to the complainant. If the Professional Conduct Committee imposes conditions or withdraws the doctor's registration, the doctor then may appeal to the Judicial Committee of the Privy Council within 28 days. The doctor will not be suspended, struck off, or have conditions placed on his registration until the Appeal has been decided.

If the complaint concerns treatment or lack of treatment by a National Health Service (NHS) General Practitioner then a complaint is made instead to the local Family Health Services Authority in England and Wales. If the complaint amounts to a complaint about an NHS hospital treatment, then the complaint is made either to the hospital itself, to the local Health Authority, or to the NHS Trust concerned. If as a result of any of these complaints it is considered there is an issue of serious professional misconduct, then the matter will be referred to the GMC for consideration.

In December, 1995 there were approximately 149,000 doctors with full registration for practice in the $\mathrm{UK}^{35}$. This amounts to 26 doctors per 10,000 inhabitants of the UK, about double the proportion of lawyers (see above).

In 19951,558 complaints were dealt with by preliminary screeners, $25 \%$ of those by lay screeners and $75 \%$ by medical screeners. This equates with 1 complaint per 100 practitioners (the lawyers' figure was 27). Of these, no action was taken in $50 \%$ of the cases. $1 \%$ were withdrawn, $12 \%$ were referred to the NHS, and complainants were invited to tender further evidence in $15 \%$ of cases. A further $6 \%$ were dealt with under chapter XV of the standing orders, which allows the GMC to write to the doctor giving the doctor advice in relation to the subject matter of the complaint if the doctor

35 GMC Annual Report, 1995. P16 
agrees with the facts of the complaint, and the final $15 \%$ were referred to the Preliminary Proceedings Committee.

Of those cases that were referred to the Preliminary Proceedings Committee in 1995, $38 \%$ concerned complaints about medical treatment and $62 \%$ were in relation to the doctor's behaviour. Of those cases which concerned the doctor's behaviour $30 \%$ related to improper relationships and $22 \%$ involved dishonesty ${ }^{36}$.

59 of the 148 cases relating to other aspects of doctors' behaviour were in response to criminal conviction and a further 89 were for alleged serious professional misconduct. Overall those cases that were considered by the Preliminary Proceedings Committee in 1995 resulted in the following outcomes ${ }^{37}$ :-

\section{Outcome Of The Complaint}

Case adjourned for a further meeting

No action was taken

Letter of advice or admonition was sent

to the doctor

Case adjourned to follow

health procedures

Case referred to the Health Committee

Case referred to the PCC

Total

\author{
Number And Percentage Of \\ Complaints \\ $16 \quad(7 \%)$ \\ $17 \quad(7 \%)$ \\ $74(31 \%)$ \\ $14(6 \%)$ \\ $2(1 \%)$ \\ $117 \quad(48 \%)$ \\ $240(100 \%)$
}

The number of cases referred to the Professional Conduct Committee are equivalent to 0.0785 per 100 medical practitioners. This compares with the 0.41 cases per 100 lawyers. The outcome of cases referred to the Professional Conduct Committee in 1995 is as follows: $27 \%$ of cases were concluded with the finding of no serious professional misconduct, in $19 \%$ of cases the doctor was admonished, in $16 \%$ there was conditional registration, in $13 \%$ of cases there was a suspension of the doctor's name on the register and in $25 \%$ of cases the doctor was struck off the Register ${ }^{38}$.

108 cases were dealt with under Chapter XV of the standing orders, meaning that the medical screener decided that referral to the PPC was not justified on the basis that the doctor's GMC registration would not be curtailed or erased, however the doctor's behaviour was not acceptable professional conduct. The decision of the screener would then have been considered by at least one medic and one layman with the PPC. This would result in a letter being sent out to the doctor to give him advice on the subject. $6 \%$ of these cases were to do with advertising, $74 \%$ were primarily to do with treatment, dishonesty primarily accounted for $2 \%$, personal conduct $10 \%$ and leaving her/his position as doctor without due notice or not taking up a post as a doctor accounted for $8 \%$.

\section{Comparison}

\footnotetext{
$36 \quad$ GMC Council Paper 21-22 ${ }^{\text {nd }}$ May, 1996. P A12.

37 GMC Council Paper 21-22, May 1996 , Figure 4

$38 \quad$ Ibid Fig.5.
} 
It is noticeable that there are twice as many doctors per head of population as lawyers. The numbers of complaints per doctor were very much smaller, with 1 complaint per hundred as compared with 27 complaints per hundred lawyers. Approximately $70 \%$ of complaints to the SCB are mediated by the Bureau and no further action is taken. For doctors approximately $50 \%$ of cases result in no further action.

Both doctors and lawyers have a forum which deals with serious complaints. .0785 cases per 100 medical practitioners went to the professional conduct committee, whereas 0.41 cases per 100 lawyers went to the Solicitors Disciplinary Tribunal.

All in all, many more complaints appear to be made against lawyers than doctors and a much larger proportion of complaints go to a serious tribunal with the possibility of striking the professional off the register or the roll. Any further comparison of the two professions must take into account that in the UK, most medical work is carried out under the National Health Service, and patients do not pay directly for these services. The result is that patients are less likely to complain about a service for which they do not make payment. Patients also need to be registered with a general practitioner and such registration relates not only to an individual but also to the rest of the family. Accordingly making a complaint against a practitioner on the medical side may mean that the entire family needs to find another doctor. Patients will often need to return to their doctors and so registration is important.

Although many lawyers will also be working for clients on legal aid, legal aid only covers a fairly small proportion of the population and even those who are eligible for legal aid may need to pay something towards their lawyer's work. One does not need to be registered with a particular lawyer either. So, if one lawyer is the subject of a complaint the client may always go to another. It would therefore be wrong to make simplistic comparisons between the two professions, but some understanding of the complaints systems and numbers of complaints within each is helpful in understanding the cultural climate in which each exists. Together with information from other jurisdictions, some baseline data will enable further comparison and analysis in the future.

\section{Major Issues For Legal Ethics in England and Wales .}

Some issues currently under discussion in England and Wales are conflict of interest, a solicitors duty to advise the client of the risks and costs of pursuing legal action, specialisation, sole practitioners, and the nature of legal ethics themselves.

\section{Conflicts of Interest}

Conflict of interest is a perennial difficulty for solicitors as can be seen from the recent number of conflict of interest cases which reach their way to the courts in comparison with other complaints against solicitors. One example of the type of 
conflicts which arise can be illustrated by Halifax Mortgage Services ltd (formerly BNP Mortgages Ltd) Stepsky [1995] 4 All ER 656, where the solicitor was acting for both the lender and the borrower in the same transaction. The conflict arises as a result of the solicitor's duty of confidentiality towards the one client, and the duty to disclose information which may be prejudicial to the other client.

This case is typical of a recent spate of cases where a spouse is a party to the mortgage of the matrimonial home which is mortgaged to an institutional lendcer for the advancement of capital for the other spouse's business. Then the business fails and the building society seeks repossession of the property. The unwitting spouce challenges this on the basis that the mortgage was entered into on her part due to a misrepresentation or undue influence by, usually, the husband. This particular case allowed the High Court to clarify the leading authorities on this point, namely Barclays Bank Plc v O’Brien [1993] for All ER 417, and CIBC Mortgages Plc v Pitt [1993] 4 All ER 433.

The pertinent point in this case as regards professional ethics is the fact that the client's solicitor acted for both the lender and the borrowers in this transaction, and $\mathrm{Mr} \mathrm{S}$ the client informed his solicitor that the cash advance would be used to pay off existing business debts, a mortgage and cover the costs of legal fees. The solicitor was seen to be in breach of his duty to the lender by not informing him that the purpose for the re-mortgage was not that which had been stated on the application (to buy shares for both the husband and the wife) but instead for the purpose which the client told the solicitor. The re-mortgage was in fact being used to discharge the business debts of the husband and was not for the direct benefit of the wife.

The difficulty is highlighted in The Law Society's Conveyancing Handbook 1994 by Silverman, which states that if a solicitor discovers that the information supplied by the client should be passed on to the lender, the solicitor cannot break the duty of confidentiality and pass that information on. This is because the information is confidential to the client. If the client is not willing to allow the solicitor to pass on the information to the lender, then the solicitor has to inform the lender that a conflict of interest has arisen and that he can no longer act on the lender's behalf. He will not however be able to give reasons for the decision other than the fact that a conflict of interest has arisen ${ }^{39}$.

In this instance it was held that that a solicitor was not permitted to pass on the information to the lender's solicitor and the lender was entitled to assume that the facts as stated on the application form were correct, as the only way to discover otherwise would have been to ask the solicitor who was unable to pass this information on to the lender. The lender therefore was considered not to have constructive notice that the loan would only be used for the benefit of the husband and not for both parties and so the lender was entitled to enforce its right to possession. If however, the solicitor had declined to act on the basis of a conflict of interest, this would have put the lender, it is presumed, on warning that there was information which the solicitor had relating to the mortgage, which could adversely affect the lender's rights and may therefore have precipitated further investigation by the lender,

39 New rules recently approved by Law Society Council attempt to deal with the problem of acting for borrower and lender. 
who would have discovered the real purpose of the loan. It may be that if those circumstances had arisen, the lender would have been imputed to have constructive notice and therefore the legal charge would not have been enforceable, although this is a matter of some conjecture at present.

Another instance of conflict occurs when a solicitor moves from one firm to another, and comes into contact with a case in which he acted for the other side in his previous firm. In the recent case of Re a firm of solicitors [1995] 3 All ER 482, a partner in a firm who acted for the plaintiffs in an action left that practice and joined a second firm which were subsequently instructed by the defendants. On the facts it was held that there was no real risk that the partner had come into contact with knowledge which could be used against the plaintiffs by the defendants, however the burden of proof was on the partner to demonstrate this. There is however no general rule which prevents a solicitor from acting against a former client of his or her former firm.

\section{Information on Costs}

An issue of professional conduct which was highlighted in the recent Annual Report delivered by the Legal Services Ombudsman was the duty on a solicitor to explain fully to the client the risks of litigation and the costs implications, and therefore not to encourage litigation when the prospects of success are low. This is covered by rule 15(2)c) of the Practice Rules which covers information which should be provided to clients at the outset and during the conduct of the case, and in addition the written professional standards on costs for clients (P226-231 of the Guide To Professional Conduct Of Solicitors 1996) and written professional standards standard (f) which states that "In all matters a solicitor should consider with clients whether the likely outcome will justify the expense or risk involved." The Guide goes on to state that it is in the interests of the solicitor as well as the client that advice should be given or confirmed in writing each time a review of this nature is carried out during the course of the case. A breach of this standard will amount to a prima facie breach of the inadequate professional services provisions, although the OSS's power in this instance only extends as far as reducing the solicitor's bill ${ }^{40}$.

In May 1997 the Law Society issued for consultation a new version of Rule 15 which would incorporate the written professional standards on costs information into the rule itself. The intention is to clarify that there is a conduct sanction for serious or persistent breaches of the current standards and to stress the need for solicitors to provide clear written information about costs throughout the handling of a case ${ }^{41}$.

\section{$\underline{\text { Specialisation }}$}

In recent years there has been a trend towards the specialisation of solicitors and legal practices and away from general practices. This move is underpinned by the quality debate and the notion that in order to offer a good level of service it is necessary to be well read and up-to-date in specific fields of practice. There is an argument which says that this is now only possible if a practitioner limits their area of expertise, due to the increasing complexity and sheer volume of legal rules.

$40 \quad$ SCB Annual Report, 1996.

$41 \quad$ Law Society Gazette $14^{\text {th }}$ May 1997. 
There are three levels of specialisation: self-certification, accreditation and panels. Initially anyone who practised regularly in an area of law could claim to be a specialist. The definition of a specialist could therefore encompass solicitors who carried out a large volume of cases in a particular legal field but did so rather badly, and those who did not conduct as many but who did so to a very high level. From 1983 onwards the Law Society began to introduce the concept of a regulated and recognised standard of specialisation by the introduction of Specialist Panels of solicitor members who had proved their ability by peer-review- interview and written test. Five subject areas have now been brought under the heading of the Law Society's Panel Scheme [with the number of members as at 31/7/96]. Medical Negligence (100) Children (1,597), Personal Injury (2,233). Planning (197) and Mental Health Review Tribunals (367) ${ }^{42}$.

Of late however, there has been a shift away from this conception of specialisation in an attempt to lift the general base line of competence among the majority of the profession, rather than focus attention on a small number of practitioners who reach a very high standard and become a Panel member. There is therefore a second, more general definition of specialist which runs concurrently, namely that espoused by the Family Law Committee of the Law Society ${ }^{43}$, a form of accreditation which marks out the solicitor as a competent family lawyer, but does not need a high level of specialisation or proof of expertise. Until the debate between the two specialist camps is settled, it is unlikely that other areas of law will move forward into either the Panel or accreditation forum.

Other specialist status which can be awarded to solicitors and the number obtaining this status upto 31/7/96 includes Local Government Diploma (304), Licensed Insolvency Practitioners (212), Rights of Audience in the Higher Courts (912) and Qualified to Conduct Discrete Investment Business $(87)^{44}$.

\section{Sole Practitioners: Are They To Blame?}

Approximately $41 \%$ of the 8,702 firms of solicitors in England and Wales earning above $£ 15,000$ per annum are described as "Sole Practitioners" in the records. These range from firms which really do have a single qualified solicitor, working by himself or herself sometimes from home, or even a hay loft, with just a computer and a telephone. But it can range up to firms where there is a single partner and quite a large number of assistant solicitors and/or para-legal and support staff. One particular sole practitioner was rumoured to have an entire staff of close on 100 people. The

\footnotetext{
$42 \quad$ Law Society Annual Statistical Report 1996, p.79

43 Report By The Family Law Committee to the Council Of The Law Society 1995

$44 \quad$ Ibid p.80.
} 
term "Sole Practitioner" is therefore not sufficiently definite to provide a clear description of the one element it purports to describe - the number of lawyers involved. Despite this uncertainty, the common image of such a firm is of a single solicitor with perhaps an assistant solicitor and at least one or two support staff, although it is not known how close this is to an empirical typification of the category. In 1986 only $35 \%$ of the profession came into this category and there has therefore been a $32 \%$ change upwards in the last ten years ${ }^{45}$.

Sole practitioners are often blamed for a particular type of problem within the English solicitors' profession; it is said that they are liable to commit fraud and run off with the money. Interestingly, they are not the ones most likely to be affected by negligence action. The three to five partner firm (currently some $42 \%$ of firms) have the worst statistics and reputation for negligence ${ }^{46}$ It seems that small groups of partners working together are more prone to making mistakes because they share their work and communication between them as to responsibility for particular items may not be well organised. The "Sole Practitioner" on the other hand knows what he/she knows, is perhaps more aware of his/her limitations and is used to relying on himself/herself or some form of network of external support.

So the largest proportion of claims on the Solicitors Indemnity Fund SIF, a common fund operated on behalf of The Law Society by an insurance company, The London Insurers Bureau, are made by the three to five partner firms. Fraud in 3-5 partner firms will often be covered by the SIF, up until the insured limits. Until recently, the largest number of claims on the Compensation Fund operated by The Law Society to cover fraud, were made by sole practitioners. The Compensation Fund operates as a direct promise to the public that they will never suffer as a result of a fraudulent solicitor. All solicitors pay into this fund and there is no cap on it, so in theory whatever happens the profession will pay ${ }^{47}$. But the largest fraud ever was carried out by Graham Durnford Ford, the senior partner of a 35 partner firm in Hastings in the early 1990's and all solicitors are paying into the fund an amount of $£ 13,000,000(13 \mathrm{~m})$ in order to compensate those who lost out as a result. None of the other partners in the firm were tainted by the fraud which was carried out by him individually, but the image of fraud as largely carried out within the office of sole practitioners has rather been blown by this one case. It was thought that partners would check on each other but he managed to get away without anyone knowing what he did, until a partner returning from sabbatical without much to do decided to have a look at GDF's files and turned him in. One could therefore say that the system worked to some extent, even though it was rather late.

This case among others caused the profession to reconsider whether the Compensation Fund should always be open ended and whether there should not be a cap on it. Two consultation papers in the last five years have gone out to the profession on this issue. In a sense it is the last bastion of altruism - the promise that no client will ever suffer from a fraudulent solicitor. It has therefore been difficult for

\footnotetext{
$45 \quad$ Ibid p.27.

$46 \quad$ A Solicitors Indemnity Fund Reports 1989 onwards.

47 The Source is Solicitors Act 1974 S.32, but there are Guidance Rules for the Compensation Fund, which is discretionary.
} 
reformers to make a change. It is also not known what reaction ACLEC or the government might have to the removal of volunteerism in terms of compensation.

Other approaches to handling the general problem which have been suggested include the need for everyone to practice in firms with at least two solicitors. Sole practitioners have therefore been quite an easy target for blame.

In addition, within areas such as Legal Aid Franchising it became clear that management of smaller law firms, especially those with just one lawyer, was starting to be problematic in ensuring competence or quality through any internal method of supervision and review. All in all sole practitioners seemed to be being blamed for many problems in the profession. As usual the big battalions of the wealthy commercial law firms were complaining about the cost of supporting the smaller players in the field.

Could the ethical conduct of a sole practitioner be assured without the professional double check of partners? The circumstances might be different in the current market environment with much less money to be earned from conveyancing property sales and legal aid monies beginning to dry up, as well as much more competition both between lawyers and from external forces. It may be the case that there are now too many reasons for lawyers to be involved, if unchecked, in unethical behaviour.

As a result of this attack on them sole practitioners began to unite and fight back. The first move was a demand that the Law Society Council include one seat specifically to represent the interests of sole practitioners. This needed a change in Council by-laws and statutes, but it happened. The sole practitioners set up a committee and interest group which publishes its own newsletter and provides information and help to those in practice by themselves. The newsletter is sent without request to all those who appear to be sole practitioners. As a result of all this activity, the small firm has had the opportunity of fighting back. The decision about whether to cap the compensation fund has not yet been made and so the last bastion of altruism remains, though the mutuality of the insurance fund is starting to break apart. It will soon be possible for firms to build up a claims history and therefore those firms with high levels of insurance claims may have to pay more to get their insurance. This will have the effect of skewing insurance payments closer to fault, rather like road traffic insurance, than before.

Although more of the 8,700 odd firms are sole practitioners than any other size of firm, the bulk of solicitors work within the largest firms (see above). In the long run it may be difficult for sole practitioners to maintain their status without further, stringent ethical provisions or costs to them.

\section{What are Legal Ethics?}

An issue which underlies all discussions of legal ethics and is beginning to have some effect at the regulatory and educational levels is much more fundamental and questions the nature of legal ethics in principal. 
A positivist or "black letter law" view would detail legal ethics as simply the regulations passed under some sort of statutory framework which are called "principles of conduct "or" legal ethics". If an issue is covered in those regulations then it is a matter of legal ethics and if it is not so covered it will not be a matter of legal ethics. There are clearly a number of difficulties even on the face of the regulations with this sort of approach. Some codes of conduct are quite short and may be written in a vague, exhortatory fashion, rather like a statute or code in a civil law country. In other jurisdictions a legal profession might decide to spell out the details, so far as is possible, of regulations going to some 600 or 700 pages. It is likely to be the case that similar ethical issues arise in each of those jurisdictions, but the regulations drafting policy is simply different. It is even possible that the regulatory approach is similar even though the mode of regulations is different.

In such widely differing systems it is also possible that the distinctions between a common law approach and a civil law approach to legal reasoning also become clear. Hence, legal ethical regulation may be seen as simply another set of rules to find one's way around. This places legal ethics in the same context as all other laws, which they are not the same context as all other laws, which they are not.

As legal professions themselves develop, they need different rules to govern the way in which they work. Government or society may also dictate changes in approach or rules. It has been suggested by moral historians that morality was simply another way in which one class exerted influence over another. In terms of early legal ethics writings, Carlin's work on Sole Practitioners seems to suggest that this was at least true for the rules of ethics in Chicago ${ }^{48}$. Large and wealthy firms of lawyers dictated to small lawyers who worked for the poor how they could, and could not, do their business. The lawyers who ran professional organisations and policed the conduct book usually came from one class and those who were affected by the rules, came from another. Indeed a brief survey of the rules of "etiquette" existing in 1974 for solicitors in England and Wales (the year this writer qualified - published as "A Guide to the Professional Conduct of Solicitors" 1974, 229 pages) shows a set of rules which are largely about how solicitors should react to each other (no competition), how solicitors should react to barristers (treat other professionals with respect) and how solicitors should react to the court. There is little about how to deal with clients.

Although all areas have grown, the current Guide $7^{\text {th }}$ Edition, 1996 has a staggering 745 pages and many of the elements of the new "conduct" rules deal mainly with safeguarding the client through rules of "competence".

As mentioned above, in England the Courts and Legal Services Act 1990 attempted to bring about an atmosphere of competition in Legal Services which attempted to deregulate the "industry" in such a way that people who were not qualified as lawyers might be able to qualify as being licensed in a small specialism of law. Deregulation brought with it a multitude of regulations for the new licensees to achieve a particular level of competence in order to safeguard the public. But if the new more limited professionals were to be covered by these rules, they also had to be shown to cover the fully qualified solicitors as well.

48 Jerome Carlin "Lawyers On Their Own”. Republished 1994, Austin \& Winfield Inc, Maryland. 
In addition the enormous growth in the numbers entering the profession in the late 1980's brought a more heterogenous group of young lawyers on stream. Coming from somewhat wider backgrounds there was a feeling that they were not policed, as previous generations may have been, by the class system. If the government were to encourage or introduce competition into the Legal Services industry then there had to be some means of ensuring quality. The idea of a social contract which enabled lawyers and other professionals to have high status relied on lawyers' altruism and the inherent quality of their work ${ }^{49}$. The effect of competition might be to undermine the altruism and to lower the quality of work to a level the profession could get away with in the market place, not what it would be proud of in the committee rooms. If law was to become a "business" then a more fully articulated code of conduct was essential. Common law lawyers were highly adept at seeing loop-holes in the law, finding ways of getting around the letter of the law on behalf of their clients and ignoring its spirit. This could not be the case for the rules of ethical conduct of the profession itself.

This takes the discussion onto a more general discourse which seems to erupt periodically in Common Law jurisdictions which questions the nature of "legal ethics". Would it not be better, suggest the purists, to call the lawyers "Code of Conduct" what it is rather than attempting to dignify it with the title of an area of moral philosophy? Legal ethics, it is said are not really about moral behaviour, in the same way that laws are not necessarily about moral behaviour but more about economic, social and political power among a ruling or governing elite. The issue has some amusement value, especially where non-lawyers consider "legal ethics" to be an oxymoron, (and especially in America where the jokes about lawyers' grasping behaviour and immorality are rife).

But sometimes an issue is raised which goes to the crux of this division between "conduct" and "ethics. An interesting example of this which has become important in the United States and is now receiving some attention in the UK is the issue of mandatory pro-bono legal work ${ }^{50}$. Beginning with Nixon's administration, money for the Legal Services Corporation has been diminished and large numbers of people who need legal services cannot afford them or obtain them. Many Bar Associations in different states have attempted to service this problem in some small way through mandatory hours of providing free legal advice or assistance in order to maintain a license as an attorney in that state. Such rules are made by the Supreme Court of each state and two states have been prominent in pushing for a mandatory number of hours. There are all sorts of exemptions and ways in which people who work in large firms can organise for someone else to do the work for them. But the real question is why lawyers should be placed in this position, as opposed to doctors, accountants, architects or butchers, bakers and candlestick makers. One might suggest on the style of Rodell ${ }^{51}$, that lawyers actually create the legal problems themselves that affect people and therefore should have an obligation to help out those who are poor and cannot afford legal services that are necessary to solve those problems. Apart from

\footnotetext{
$49 \quad$ See Paterson below

50 Jollife, D., "Mandatory Pro-Bono work for Lawyers: Professional Responsibility or Legal Enslavement?", Institute of Advanced legal Studies Seminar, $18^{\text {th }}$ March 1996. 
this notion, the only real justification for the suggestion that lawyers should operate mandatory pro-bono, as opposed to voluntary pro bono, is that they should have an altruistic, higher morality or ethical behaviour.

This then is a discreet example of an issue which provides a dividing line between a proper code of conduct and a question of higher morality. Apparently in New York State research was carried out to plumb the depths of unmet legal need and that research suggested that there were some three million issues per year that needed to be dealt with by lawyers which were not receiving that treatment. In New York the chief judge of the State Supreme Court was the most vocal proponent of mandatory pro-bono.

There was a great deal of opposition from among the lawyers. The source of the Chief Justice's argument was the moral high ground and he was advocating that lawyers be mandated to provide this service on grounds of superior morality. Unfortunately, when he was found to be involved in some issue of moral turpitude, the force of his arguments relating to pro-bono collapsed and so did the issue itself. In Florida it was a group of senior partners in larger firms who were pushing the issue of mandatory pro-bono and the reaction from the profession was so strong that it has been relaxed there as well. This particular issue therefore seems to suggest that lawyers' codes of conduct and laws of morality are rather different exercises.

It will be seen that such issues are crucial in any future definition of the principles of ethical legal conduct. The battleground over mandatory pro-bono work and whether this form of regulation should appear as part of the conduct rules, exemplifies the distinction between moral behaviour and legal ethics. Similarly, proper understanding of this issue has a major effect on the purpose of teaching of legal ethics at all stages of legal education ${ }^{52}$. If what is really intended when a Report such as the ACLEC Report, refers to teaching lawyers to be more conscious of ethics, is that they should in general behave more ethically and more morally towards their work and their clients irrespective of what the conduct rules state, then what is required is something very different from a simple knowledge element of what those conduct rules contain.

In the United States it has been essential for some time for all university law courses intending to qualify students for the profession to include a compulsory course on "legal profession". Such courses vary considerably, but they largely teach and examine their students on the statutory and conduct basis for legal rules. All of this is quite different from the intentions of Chief Justice Warren Burger, when he noted the ethical deficiencies of the American Bar soon after Watergate ${ }^{53}$. Partly as a result of his comments and exhortations the Ford Foundation funded courses on "professional responsibility" through a Council For Legal Education in Professional Responsibility, in every law school in the United States. Many of such courses operated through a "clinical" model in which students worked on real or simulated cases whilst they were at university under the supervision of teachers. It is submitted that only this model can really be helpful in discussing the detail of moral and ethical behaviour with students in the appropriate legal context. All other approaches hang around

52 See comments within ACLEC's First Report on Legal Education mentioned above.

53 Burger, W "The 1973 Sonnet Memorial Lecture" 42 Fordham L.Rev 227 (1973-4). 
knowledge acquisition of conduct rules, rather than attitude and behaviour change among aspiring lawyers. Further discussion of this issue is therefore essential for the proper development of new codes of legal ethics, teaching of legal ethics and approaches to complaints and discipline.

\section{The Trend Towards Business Enterprise As Opposed To Professionalism}

According to Paterson the concept of professionalism is a neo-contractualist one including self regulation and autonomy, ethics and a quality of service which denotes expertise $^{54}$. This concept relies on all three being present, the loss of any leading to a shift in the nature of a profession or, as now, a re-negotiation of the concept of professionalism. Gradually the legal profession has seen a number of changes which have affected its autonomous position. Firstly, reforms in relation to its conveyancing monopoly and its right to advertise, have led to an injection of competition within the profession and between the profession and outside concerns such as the financial services market, which have led to a trend towards market forces and business enterprise. Secondly, as discontent from the public with the level of service that solicitors provide, and the high fees which they can command for that service, has developed, the Government has stepped in the guise of the Courts and Legal Services Act 1990 in order to take over part of the profession's own regulatory function.

Another shift towards business enterprise has been experienced as a result of the Legal Aid franchising specifications which operate as a legal equivalent of ISO 9002 to ensure that management and administrative systems are in place within law firms. These concentrate more on management structures than the quality of the legal work which carried out within the firms, as do the practice Management Standards which the Law Society have endorsed for all law firms irrespective of whether legal aid work is undertaken. Consequently the organisation of the firm and the way in which the work is carried out and recorded is to a certain extent taken out of the hand of the solicitor and is dictated instead by the consumer in place of the consumer ${ }^{55}$. The consumer in question is of course the largest purchaser of legal services in England and Wales, the Legal Aid Board, in the case of legal aid work who will have, amongst other motives, the reduction of legal costs according to the principle of market forces.

The move towards quality assurance has led to the spotlight being turned on various aspects of legal practice which are then dissected to discover whether it is possible to measure quality within the legal profession. The charge that the profession is being deskilled as a result, and through this demystification is losing its identity and the appearance of exclusive expertise may be a fair one, although it may be a necessary step to convince the public that solicitors should be regarded as having particular expertise in the legal field. If the public have already lost faith in the ability of solicitors to provide a legal service which is better than one which could be offered by another provider, then quality assurance may be the only way to win the public and the Legal Aid Board around and therefore justify the high fees and continuing monopoly in certain types of work.

\footnotetext{
54 See Professionalism And The Legal Services Market, Alan Paterson, International Journal Of The Legal Profession Vol.3 No.1 and 21996 pp 137-168. See Hilary Sommerlad, Managerialism And The Legal profession, International Journal Of The Legal profession vol.2 no. 2/3 1995 pp.159-185.
} 
The introduction of block contracts for legal aid work could transform the present demand-led legal aid system into a system of competitive tendering between law firms and the Legal Aid Board more akin to the business environment than the traditional conception of a profession ${ }^{56}$. This is happening in "beauty contests" in the commercial context and in local authority funded areas of work with Compulsory Competitive Tendering. Legal Services have therefore become a saleable commodity, and the price fixing of the past is yet further eroded with solicitors openly price cutting in order to secure legal aid block contracts. This ethos will gradually filter through to non-legally aided firms as the culture changes in the legal services market.

\section{Conclusion}

The English solicitors profession exhibits a large amount of formal legal regulation in its code of conduct, a code so large that its contents are unlikely to be known in its entirety by all members of the profession. The profession has recently moved from being entirely self regulating, to a position where changes in conduct rules have to go before an advisory committee, which also considers the entrance of competitors into the legal services market, and also advises on legal education and training. This move away from self regulation is a clear distinction between this and other European legal professions. However, it is a governmental approach which is now being seen in some states of Australia as well, and lay involvement in disciplinary issues for the legal professions of some of the United States seems to be increasing.

There is also some lay involvement in disciplinary issues in the Law Society of England and Wales. Unhappiness about the quasi independent SCB has led to the creation of a new Office for the Supervision of Solicitors, but it is not clear yet whether this will be very different from its predecessor. A comparison of complaints statistics as between legal and medical professions in England and Wales shows some major differences with many more complaints being levelled against lawyers, but there are systemic reasons for this.

Many of the current issues for legal ethics in England and Wales are similar to those of other countries in Europe. Conflicts of interests are a problem as are the continued survival of the sole practitioner. The compensation fund for clients of dishonest solicitors, is the last bastion of pure altruism within the English legal profession. Perhaps, most important of all, the nature of legal ethics is under discussion among academics, legal professionals, regulatory bodies, and is receiving attention from the advisory body in relation to legal education and training.

Legal ethics are something of a barometer of de-professionalisation. Movements towards a commercial, or business approach, are reflected in greater regulation and more careful ethical codes. Regulatory bodies tend to be reactive rather than proactive, but the disputes over changes in ethical regulation often show up the background of power mongering within the profession itself.

$56 \quad$ Ibid. 
C: $\backslash$ Journal $\backslash$ Legal Ethics in England and Wales.doc 